\title{
Downwind evolution of the volatility and mixing state of near-road aerosols near a US interstate highway
}

\author{
Provat K. Saha ${ }^{1}$, Andrey Khlystov ${ }^{2}$, and Andrew P. Grieshop ${ }^{1}$ \\ ${ }^{1}$ Department of Civil, Construction and Environmental Engineering, North Carolina State University, \\ Raleigh, North Carolina, USA \\ ${ }^{2}$ Division of Atmospheric Sciences, Desert Research Institute, Reno, Nevada, USA
}

Correspondence: Andrew P. Grieshop (apgriesh@ncsu.edu)

Received: 24 July 2017 - Discussion started: 11 August 2017

Revised: 30 November 2017 - Accepted: 20 December 2017 - Published: 14 February 2018

\begin{abstract}
We present spatial measurements of particle volatility and mixing state at a site near a North Carolina interstate highway (I-40) applying several heating (thermodenuder; TD) experimental approaches. Measurements were conducted in summer 2015 and winter 2016 in a roadside trailer (10 $\mathrm{m}$ from road edge) and during downwind transects at different distances from the highway under favorable wind conditions using a mobile platform. Results show that the relative abundance of semi-volatile species (SVOCs) in ultrafine particles decreases with downwind distance, which is consistent with the dilution and mixing of traffic-sourced particles with background air and evaporation of semi-volatile species during downwind transport. An evaporation kinetics model was used to derive particle volatility distributions by fitting TD data. While the TD-derived distribution apportions about $20-30 \%$ of particle mass as semi-volatile (SVOCs; effective saturation concentration, $C^{*} \geq 1 \mu \mathrm{m}^{-3}$ ) at $10 \mathrm{~m}$ from the road edge, approximately $10 \%$ of particle mass is attributed to SVOCs at $220 \mathrm{~m}$, showing that the particle-phase semi-volatile fraction decreases with downwind distance. The relative abundance of semi-volatile material in the particle phase increased during winter. Downwind spatial gradients of the less volatile particle fraction (that remaining after heating at $180^{\circ} \mathrm{C}$ ) were strongly correlated with black carbon (BC). BC size distribution and mixing state measured using a single-particle soot photometer (SP2) at the roadside trailer showed that a large fraction (70-80\%) of BC particles were externally mixed. Heating experiments with a volatility tandem differential mobility analyzer (V-TDMA) also showed that the nonvolatile fraction in roadside aerosols is mostly externally mixed. V-TDMA measurements at different dis-
\end{abstract}

tances downwind from the highway indicate that the mixing state of roadside aerosols does not change significantly (e.g., $\mathrm{BC}$ mostly remains externally mixed) within a few hundred meters from the highway. Our analysis indicates that a superposition of volatility distributions measured in laboratory vehicle tests and of "background" aerosol can be used to represent the observed partitioning of near-road particles. The results from this study show that exposures and impacts of $\mathrm{BC}$ and semi-volatile organics-containing particles in a roadside microenvironment may differ across seasons and under changing ambient conditions.

\section{Introduction}

Motor vehicles are a large source of ambient fine particulate matter (PM; Dallmann and Harley, 2010; Fraser et al., 1999; Kumar et al., 2011; Zhang et al., 2015). Particles emitted from vehicle exhaust are dominated by ultrafine particles (diameters < $100 \mathrm{~nm}$; Kleeman et al., 2000; Robert et al., 2007; Zhu et al., 2002), which are a concern due to their potential impacts on public health (Health Effects Institute, 2010; Hoek et al., 2009; Pope and Dockery, 2006). Vehicle-emitted PM largely consists of primary organic aerosol (POA) and black carbon (BC; Dallmann et al., 2014; Maricq, 2007). Upon emission, vehicle exhaust undergoes rapid cooling and dilution with ambient air on the road. Emissions undergo further evolution from road to background-like conditions within a few hundred meters downwind from the roadway (Robinson et al., 2010; Zhang et al., 2004), which involves complex physicochemical processes. Subsequently, the size 
distribution and physiochemical characteristics, and thus the exposure characteristics and impacts, of aerosols evolve with downwind transport.

A large portion of POA emitted from motor vehicle is semi-volatile material (Grieshop et al., 2009; May et al., 2013a; Presto et al., 2012) that can dynamically partition into the gas or particle phases with changing ambient conditions (e.g., temperature, atmospheric dilution) and atmospheric aging (Robinson et al., 2007, 2010). At equilibrium, the volatility of organic species (saturation vapor pressure or, equivalently, saturation concentration, $C^{*}$ ) dictates gas-particle partitioning (Donahue et al., 2006). Enthalpies of vaporization $\left(\Delta H_{\text {vap }}\right)$ also influence the change in partitioning with temperature (Epstein et al., 2010; Ranjan et al., 2012). Depending on the volatility of POA and atmospheric perturbations (dilution, changing temperature), semi-volatile species in POA will dynamically partition into gas or particle phases as they move downwind. Therefore, gas-particle partitioning of POA likely plays an important role in determining human exposure to traffic-emitted particles under varied ambient conditions.

Fresh BC particles emitted from vehicles are typically fractal in morphology (Bond et al., 2013; China et al., 2014) and may have varying size, shape, and mixing state. BC may exist in the same particle as OA and others species (internally mixed) or in separate particles (externally mixed). The mixing state and morphology of $\mathrm{BC}$ particles can influence their radiative absorption properties (Cappa et al., 2012) and deposition in the human respiratory tract (Broday and Rosenzweig, 2011). The mixing state and physiochemical characteristics of $\mathrm{BC}$ particles evolve as they undergo atmospheric processing and aging (Adachi and Buseck, 2013; Subramanian et al., 2010). For example, the photochemical oxidation of volatile organic compounds (VOCs), intermediate VOCs (IVOCs), and semi-volatile organic compounds (SVOCs) forms condensable vapors. These condensable vapors can partition into the particle phase either by absorbing into the organic condensed phase or adsorbing onto nonvolatile BC cores (Donahue et al., 2006; Pankow, 1994; Roth et al., 2005).

Spatial measurements of the volatility and mixing state of near-road aerosols are critically important to better understand the evolution of vehicle-emitted POA and BC under diverse ambient conditions (e.g., seasons) as they are transported from roadways to assess human exposure and health risks and to improve their representation in air quality and exposure assessment models. Although a number of laboratory and field studies have investigated the volatility (Kuwayama et al., 2015; May et al., 2013a, b; Li et al., 2016; Biswas et al., 2007; Grieshop et al., 2009) and mixing state (Tiitta et al., 2010; Liu et al., 2014; China et al., 2014; Willis et al., 2016) of traffic-emitted particles using various techniques, they have largely focused on source characterization or measurements at a fixed ambient location. To the best of our knowledge, no studies have been conducted to system- atically explore the evolution of volatility and mixing state of near-road aerosols at different distances from the roadway under diverse environmental conditions.

We measured the evolution of a highway plume at different downwind distances under diverse environmental conditions under favorable wind directions during summer and winter field campaigns. Heating (using a thermodenuder) experimental data coupled with a mass transfer kinetics model were used to investigate particle volatility, and heating (VTDMA: volatility tandem differential mobility analyzer) and single-particle data (SP2: single-particle soot photometer) were used to explore the mixing state of particles. The objectives of the study were to (i) determine the spatial distribution of aerosol volatility and mixing state in a near-road microenvironment, (ii) explore the influence of seasonality and ambient conditions on the phase partitioning of nearroad aerosols, and (iii) evaluate the representativeness of laboratory-derived POA volatility distributions from vehicle exhaust to explain real-world observations of aerosol volatility in a complex near-road microenvironment.

\section{Methods}

\subsection{Measurement sites}

Two month-long measurement campaigns were conducted at a site near Interstate 40 (I-40) outside Durham, North Carolina $\left(35.865^{\circ} \mathrm{N}, 78.820^{\circ} \mathrm{W}\right)$ in summer 2015 (1 June2 July) and winter 2016 (18 January-20 February). A map of the measurement site is shown in Fig. S1 in the Supplement. Detailed descriptions of the measurement site and campaigns are included in Saha et al. (2018); they are only described briefly here. At the measurement location, I-40 has eight lanes and an annual average daily traffic volume of 140 to 145 thousand vehicles per day (4-6\% of which are heavy-duty diesel vehicles; HDDVs). At our site, I-40 adjoins a low-traffic rural road running almost perpendicular to the highway, which is in line with the dominant wind direction (southwest; $225^{\circ}$ ). This minor road allows us to study the evolution of the highway plume at different downwind distances.

Measurements were collected at a fixed-site trailer located $10 \mathrm{~m}$ from the highway (continuous) and during downwind transects on the minor roadway at different downwind distances $(10,50,100,150,220 \mathrm{~m})$ from the highway (intermittent). Downwind transect measurements were performed on weekdays with the wind coming off the highway consistently in summer (4 days) and winter (3 days). A mobile platform (van) was used for transect measurements. For a particular transect run, a sampling period at a downwind point was $\sim 20 \mathrm{~min}$; four to five downwind points were sampled consecutively. During sampling, the van engine was off to avoid self-contamination. A "full transect run" took approximately $2 \mathrm{~h}$. Typically, three transect runs were completed per 
day: morning rush hour $(\sim 07: 00-09: 00)$, midday $(\sim 12: 30-$ $14: 30)$, and evening rush hour $(\sim 16: 30-18: 30)$. To explore the spatial distribution of the volatility and mixing state of particles, measurements collected during transect runs are the major focus of this paper.

\subsection{Measurements}

\subsubsection{Thermodenuder (TD) experiments}

Various configurations of heating (thermodenuder; TD) experimental approaches were applied to explore the volatility and mixing state of near-road aerosols. The methods applied here fall into two general categories: (i) heating of the polydisperse particle distribution (Huffman et al., 2008; Lee et al., 2010; Saha et al., 2017) and (ii) heating of monodisperse particles selected by the differential mobility analyzer (DMA-selected; volatility tandem DMA approach, VTDMA; Biswas et al., 2007; Kuhn et al., 2005; Tiitta et al., 2010). A custom-built, multi-tube thermodenuder (MT-TD) system was used for high-time-resolution volatility measurements. The MT-TD consists of four separate heated lines controlled by automated valves that can be switched in approximately $1 \mathrm{~s}$, enabling quick alternation among four different set temperatures. While measuring the evaporation of a polydisperse distribution, the MT-TD was coupled with a scanning mobility particle sizer (SMPS; TSI Inc.; 3010 CPC, 3081 DMA; scan time $2.5 \mathrm{~min}$ ) to measure thermodenuded distributions (10-400 nm) after heating at 60, 90, 120, and $180^{\circ} \mathrm{C}$ with a residence time (Rt) of $30 \mathrm{~s}$. All Rt values reported in this paper are volumetric residence time at room temperature unless otherwise stated. Dump flows were used to maintain constant flow in all lines during MT-TD operation. A full set of temperature scans required $\sim 10 \mathrm{~min}$. Another SMPS (3010 CPC, 3081 DMA; scan time $2.5 \mathrm{~min}$ ) continuously measured particle size distributions $(10-400 \mathrm{~nm})$ at ambient temperature. In a subset of transect runs, the VTDMA configuration was used. In this approach, DMA sizeselected monodisperse particles $(25,50,100,250 \mathrm{~nm})$ were heated at different TD temperatures $\left(60-180^{\circ} \mathrm{C}\right)$ with an Rt of $30 \mathrm{~s}$ and the thermodenuded distributions were measured using an SMPS.

In the stationary roadside trailer, a temperature stepping TD (TS-TD; Huffman et al., 2008; Saha et al., 2017) was continuously operated at four temperature steps (60, 90, 120, $\left.180{ }^{\circ} \mathrm{C} ; \mathrm{Rt}=30 \mathrm{~s}\right)$ upstream of an aerosol chemical speciation monitor (ACSM; Aerodyne Inc.; 75-650 nm) and SMPS $(10-400 \mathrm{~nm})$. In this configuration, instruments were alternated between the bypass (ambient) and TS-TD lines at $10 \mathrm{~min}$ intervals using an automated three-way valve. TDACSM provides chemically resolved (organic, sulfate, nitrate, ammonium, and chloride) volatility data. Because TD data at different residence times provide additional constraints on the volatility parameter extraction process (Saha et al., 2015, 2017), TD-SMPS data (10-400 nm) using the
MT-TD setup were collected over a wide range of temperature and Rt conditions $\left(T=60,90,120^{\circ} \mathrm{C} ; \mathrm{Rt}=9,13,19\right.$, $30 \mathrm{~s}$ ) during some of the summer campaign at the roadside trailer. An extra flow controller was used to vary Rt (Saha et al., 2015). In all measurements, a silica gel diffusion dryer was placed upstream of TD inlets and aerosol instruments to maintain relative humidity $(\mathrm{RH})<30-40 \%$.

\subsubsection{Single-particle soot photometer (SP2)}

An SP2 (Droplet Measurement Technologies) was deployed at the roadside trailer during the winter campaign to measure the size distribution and mixing state of BC. The SP2 uses a laser-induced incandescence (Nd:YAG laser; $1064 \mathrm{~nm})$ technique (Stephens et al., 2003) to measure refractory BC mass (rBC) in individual particles. The rBC-containing particles passing through the laser beam scatter laser light and at the same time absorb energy and are heated to their vaporization temperature and incandesce (McMeeking et al., 2011a; Moteki and Kondo, 2007; Shiraiwa et al., 2007; Stephens et al., 2003). The incandescent light is proportional to rBC core mass. The SP2 incandescence response was calibrated with DMA-selected dried fullerene soot particles. A calibration curve is derived from the SP2 incandescence response and mass of the calibration particles from the mobility diameter and assuming an effective density of $1.8 \mathrm{~g} \mathrm{~cm}^{-3}$. The scattering detectors were calibrated using dried PSL (polystyrene latex sphere) particles by relating the detector response to the PSL sizes. Ambient particles were dried before introduction into the SP2.

\subsubsection{Other supporting measurements}

Measurements of traffic (volume, composition, speed), meteorological data (ambient $T, \mathrm{RH}$, wind speed, and direction), and various gaseous and particulate air pollutant concentrations were collected throughout the campaigns and are discussed in detail in Saha et al. (2018). A 10 m meteorological tower recorded meteorological data at the roadside trailer location. An existing remote traffic microwave sensor (RTMS) maintained by the North Carolina Department of Transportation (NC-DOT) provided traffic data. Particle size distributions (SMPS; 10-400 nm), chemical composition (ACSM; 75-650 nm), BC (photoacoustic extinctiometer; PAX-870; Droplet Measurement Technologies), $\mathrm{NO} / \mathrm{NO}_{2}$ (2B Technology 401/410), and $\mathrm{CO}_{2}$ (Li-cor Li-820) were continuously measured at the roadside trailer. During transect runs, particle sizing (SMPS), $\mathrm{NO}, \mathrm{NO}_{2}, \mathrm{BC}$, and $\mathrm{CO}_{2}$ instruments from the trailer were placed in the transect van to collect these parameters at different distances from the highway. Particle size distribution (SMPS; 10-400 nm), NO/NO 2 (Ecotech 9841), and $\mathrm{BC}$ (microAeth AE51) were continuously monitored in an upwind stationary background site located on the opposite side of I-40 approximately $400 \mathrm{~m}$ away from the highway. 


\subsection{Data reduction}

Evaporation of particles at a particular TD operating condition $(T, \mathrm{Rt})$ is described in terms of volume fraction remaining (VFR; for SMPS data) or mass fraction remaining (MFR; for ACSM data). VFR (MFR) is the ratio of volume (mass) concentration measured in heated line $\left(C_{\mathrm{TD}}\right)$ to that in unheated bypass line $\left(C_{\mathrm{BP}}\right)$. The size distribution for the heated, size-selected monodisperse particles (V-TDMA approach) was typically bimodal; one mode did not shrink upon heating (nonvolatile mode) and the other did (volatile mode). VFR for the size-selected particles was estimated as $\left(D_{\mathrm{p} \text {, heated }}\right)^{3} /\left(D_{\mathrm{p} \text {, ambient }}\right)^{3}$, where $D_{\mathrm{p} \text {, ambient }}$ is the mode diameter of the selected monodisperse particles at ambient temperature and $D_{\mathrm{p}}$,heated is the mode diameter of the volatile mode after heating at a particular temperature. Therefore, estimated VFR for the size-selected particles excludes the nonvolatile population. Empirical particle loss correction factors (Saha et al., 2015), estimated as a function of TD operating conditions $(T, \mathrm{Rt})$, were applied to the VFR from integrated SMPS volume and MFR from ACSM data. Because VFR for size-selected particles was calculated from the change in mode diameter, particle loss correction factors are not required in this calculation.

SP2 data were processed using the PSI (Paul Scherrer Institute) SP2 Toolkit. The rBC-containing particles are treated as an $\mathrm{rBC}$ core coated by a shell of other material. The size distribution of $\mathrm{rBC}$ cores was derived based on the mass equivalent diameter (MED) of an rBC core assuming a density of $1.8 \mathrm{~g} \mathrm{~cm}^{-3}$. The delay time between the peak of the incandescence and scattering signals is an indicator of the coating thickness (mixing state; Moteki and Kondo, 2007) and was used to determine the number fraction of "thinly coated" and "thickly coated" rBC particles (McMeeking et al., 2011a; Shiraiwa et al., 2007; Subramanian et al., 2010).

\subsection{Parameterizing volatility}

An evaporation mass transfer kinetics model (Lee et al., 2011) was applied to infer particle volatility distributions by fitting TD data. The volatility distribution extraction framework used here is similar to that described in Saha et al. (2015). The resulting fit empirically describes the particle volatility distribution using a volatility basis set (VBS) framework (Donahue et al., 2006, 2012), in which the material is lumped over a logarithmically spaced set of $C^{*}$ (effective saturation concentration) bins at a reference temperature of $25^{\circ} \mathrm{C}$. A set of $f_{i}$ describes the distribution of semi-volatile species (particle + gas phase) in selected $C^{*}$ bins under a gas-particle equilibrium and is usually known as a volatility distribution. A six-bin $\log _{10}$ VBS with a $C^{*}$ bin range of $10^{-4}$ to $10^{1} \mu \mathrm{g} \mathrm{m}^{-3}$ at $25^{\circ} \mathrm{C}$ was selected to describe the particle volatility distribution empirically. Before the TD inlet, an initial gas-particle equilibrium at ambient temperature (summer $30^{\circ} \mathrm{C}$, winter $5^{\circ} \mathrm{C}$ ) and campaign- average aerosol mass loading $\left(C_{\mathrm{OA}} \sim 5 \mu \mathrm{g} \mathrm{m}^{-3}\right)$ were assumed. The Clausius-Clapeyron equation was applied to calculate temperature-dependent $C^{*}$ (Saha et al., 2015).

The mass transfer kinetics model tracks particle- and gasphase concentrations of the surrogate species (represented by $C^{*}$ bins) as they pass through the TD. The TD-derived volatility distributions from kinetics model fits are sensitive to assumptions of the enthalpy of vaporization $\left(\Delta H_{\mathrm{vap}}\right)$ and evaporation coefficient $\left(\gamma_{\mathrm{e}}\right)$; these values are generally unknown a priori (Cappa and Jimenez, 2010) and $\gamma_{\mathrm{e}}$ is often assumed to be in unity in fitting TD data (Grieshop et al., 2009; $\mathrm{Li}$ et al., 2016). However, recent studies reported $\gamma_{\mathrm{e}}$ values between 0.01 and 1 for different aerosol systems (Cappa and Jimenez, 2010; Saha et al., 2017; Saha and Grieshop, 2016; Saleh et al., 2013). Similarly, in the literature, different ranges of $\Delta H_{\text {vap }}$ values are reported for different aerosol systems (Epstein et al., 2010; May et al., 2013c; Ranjan et al., 2012). TD data collected at varying $T$ and Rt provide additional constraints on feasible $\gamma_{\mathrm{e}}$ and $\Delta H_{\mathrm{vap}}$ values (Saha et al., 2015, 2017; Saha and Grieshop, 2016). TD data over a wide range in $(T, \mathrm{Rt})$ space were collected during the I-40 summer campaign at the near-road trailer and are shown in Fig. S2a-d. Following Saha et al. (2015, 2017), we used this data set to optimize a set of $\gamma_{\mathrm{e}}$ and $\Delta H_{\mathrm{vap}}$ values that best explain the evaporation observed in near-highway aerosols (see Fig. S2e for details). A $\gamma_{\mathrm{e}}$ value of 0.25 and $\Delta H_{\mathrm{vap}}$ of $100 \mathrm{kj} \mathrm{mol}^{-1}$ provided the overall best fit for this data set. We adopted these estimated $\gamma_{\mathrm{e}}$ and $\Delta \mathrm{H}_{\mathrm{vap}}$ values for the nearhighway aerosol system for further fitting of TD data from different distances from the highway across all seasons and sizes. Saha et al. (2017) reported similar $\gamma_{\mathrm{e}}$ and $\Delta H_{\mathrm{vap}}$ values for ambient TD data from two sites in the southeastern US under diverse conditions. Saleh et al. (2012) derived a $\gamma_{\mathrm{e}}$ value of $0.28-0.46$ for ambient aerosols in Lebanon. Therefore, given the consistency in reported $\gamma_{\mathrm{e}}$ and $\Delta H_{\mathrm{vap}}$ values across diverse settings (Saha et al., 2017; Saleh et al., 2012), it is reasonable to use constant values for further fitting of TD data from the same site under different conditions. Other inputs to the mass transfer model include diffusion coefficient $(D)$, surface tension $(\sigma)$, molecular weight (MW), and density $(\rho)$; the assumed values generally have a smaller influence on modeled evaporation in TDs (Cappa and Jimenez, 2010; Saha et al., 2015) and are approximated from the literature (Table S1 in the Supplement).

\section{Results and discussion}

\subsection{Observed evaporations in TD with downwind distance}

Figure 1 shows the measured VFR at $60^{\circ} \mathrm{C}$ as a function of distance from the highway. The particle volume fraction that evaporates at low and moderate TD temperature (e.g., VFR at $60^{\circ} \mathrm{C}$ ) consists of semi-volatile species, presum- 
ably OA. VFR data are shown for different monodisperse particle sizes (e.g., 25, 50, 100, $250 \mathrm{~nm}$ ) and for the integrated volume of polydisperse distributions. Results shows that the evaporation observed in a TD at $60^{\circ} \mathrm{C}$ decreases with downwind distance during transects in both seasons, which suggests a reduction in the relative abundance of the semi-volatile fraction in particles with distance. This reduction is especially pronounced over the ultrafine particle range $(<100 \mathrm{~nm})$. Two plausible reasons could contribute to this observation. First, a fraction of semi-volatile species in vehicle-emitted fresh particles may be evaporating during transport due to dilution-driven processes (Choi and Paulson, 2016; Robinson et al., 2007; Shrivastava et al., 2006). Second, since the concentration of vehicle-emitted particles decreases rapidly with distance from the highway, the relative proportion of background particles in the sampled aerosol (vehicle-emitted + background) increases with distance. If one assumes that background particles are less volatile than vehicle-emitted fresh particles, the relative abundance of the less volatile material in the sampled aerosols will increase with distance. The influence of each factor cannot be isolated directly from TD measurements. However, the particle size distributions measured at background (upwind) and downwind locations from the highway (Fig. S3) indicate that vehicle-emitted fresh particles are dominated by ultrafine particles $(<100 \mathrm{~nm})$, while background particles are predominantly in a relatively larger mode. When polydisperse particles $(10-400 \mathrm{~nm})$ were heated at a moderate TD temperature $\left(60^{\circ} \mathrm{C}\right)$, the changes in the larger size range $(>100 \mathrm{~nm})$ were observed to be minimal (Fig. S4). Larger particles also do not show significant downwind gradients in evaporation upon heating at $60^{\circ} \mathrm{C}$ (Fig. S4). Therefore, the observed downwind decrease in the evaporation of ultrafine particles at $60{ }^{\circ} \mathrm{C}$ is likely more influenced by the dilution-driven losses of semi-volatile species during downwind transport. It should be noted here that other processes, including coagulation, may influence the evolution of near-road aerosol size distribution. However, Zhang et al. (2004) reported that after the initial stage of dilution (tailpipe to on-road), the second phase (road to ambient) of aerosol size distribution evolution is dominated by condensation and dilution, while coagulation and deposition play minor roles. Therefore, we do not expect that coagulation is a dominant process in altering the physiochemical properties of transported traffic particles within the near-road domain (10-200 m from the highway edge) where we conducted our measurements.

The general trends in evaporation at $60^{\circ} \mathrm{C}$ observed as a function of downwind distance were consistent between summer and winter (Fig. 1). However, the evaporation observed in winter was slightly greater than that in summer, specifically closer to the highway and for smaller particles. This observation is consistent with that of Kuhn et al. (2005), who reported greater evaporation of near-road particles in winter at a particular TD temperature. Two possible factors may contribute to this inter-seasonal difference. First, the ini- tial partitioning of SVOCs entering the TD is different; at colder temperatures, a higher fraction of semi-volatile materials is expected to partition into the particle phase. An analysis of temperature effects on the partitioning of semivolatile materials from vehicular emissions (see Fig. S5) indicates that while $40-70 \%$ of semi-volatile emissions reside in the particle phase under typical winter conditions $(0$ $10^{\circ} \mathrm{C}$ ), only $10-20 \%$ do so under summer conditions $(20$ $30^{\circ} \mathrm{C}$ ). This analysis used the gasoline POA volatility distribution from May et al. (2013a) and $\Delta H_{\mathrm{vap}}$ from Ranjan et al. (2012) and considered a range of OA concentrations for a typical roadside environment (e.g., 0.5 to $5 \mu^{-3} \mathrm{~m}^{-3}$ ). Second, the difference could be due inter-seasonal differences in emission properties (the volatility of emissions) and atmospheric dilution. The effect of these two effects cannot be isolated directly from TD observations, but the application of an evaporation kinetics model can disentangle them to some extent. For example, during modeling, initial gasparticle equilibrium at ambient temperatures (winter $\sim 5^{\circ} \mathrm{C}$, summer $\sim 30^{\circ} \mathrm{C}$ ) was assumed before the TD inlet, which will account for the ambient temperature effect on initial SVOC partitioning. Therefore, inter-seasonal differences in the volatility of emissions (if any) should be reflected in the resulting fitted volatility distributions; these modeling results are discussed in Sect. 3.3.

Figure 2 shows the evaporation observed at a higher TD temperature $\left(180^{\circ} \mathrm{C}\right)$. VFR of $\mathrm{PM}_{0.4}$ (integrated volume between 10 and $400 \mathrm{~nm}$ ) at $180^{\circ} \mathrm{C}$ decreases with downwind distance. The particle volume fraction that does not evaporate at $180^{\circ} \mathrm{C}$ will consist of $\mathrm{BC}$, other refractory materials (e.g., metals, crustal materials), and/or extremely low-volatility organics (ELVOCs; $C^{*}<10^{-3} \mu \mathrm{g} \mathrm{m}^{-3}$; Donahue et al., 2012). ELVOCs in the atmosphere are formed from multiple sources and chemical processes (Ehn et al., 2014; Jokinen et al., 2015). Organic mass fraction remaining (OA MFR) at $180^{\circ} \mathrm{C}$ measured in the roadside trailer $(\sim 10-20 \%)$ using the TDACSM likely provides an approximate estimate of ELVOCs (shown with green circles in Fig. $2 \mathrm{a}$ and b). Similar values were measured during ambient TD measurements in urban background and rural sites in the southeastern US (Saha et al., 2017). Recent laboratory-derived POA volatility distributions suggest that the presence of ELVOCs in fresh trafficemitted POA may not be significant (May et al., 2013a, b). Therefore, as a first-order approximation, ELVOCs measured in the near-highway environment are likely dominated by regional background aerosol, and thus a gradient downwind of the roadway is not expected. On the other hand, traffic emissions are a major contributor of BC in near-highway environments (Baldauf et al., 2008; Bond et al., 2013; DeWitt et al., 2015) and a rapid downwind decay of BC concentrations was observed in our site (Saha et al., 2018), which is consistent with past studies (Karner et al., 2010).

The downwind gradients of VFR of $\mathrm{PM}_{0.4}$ at $180^{\circ} \mathrm{C}$ correlate well with that of $\mathrm{BC}$ (Fig. $2 \mathrm{a}$ and $\mathrm{b}$ ). A less sharp decay of BC during winter was also consistent with the gradi- 

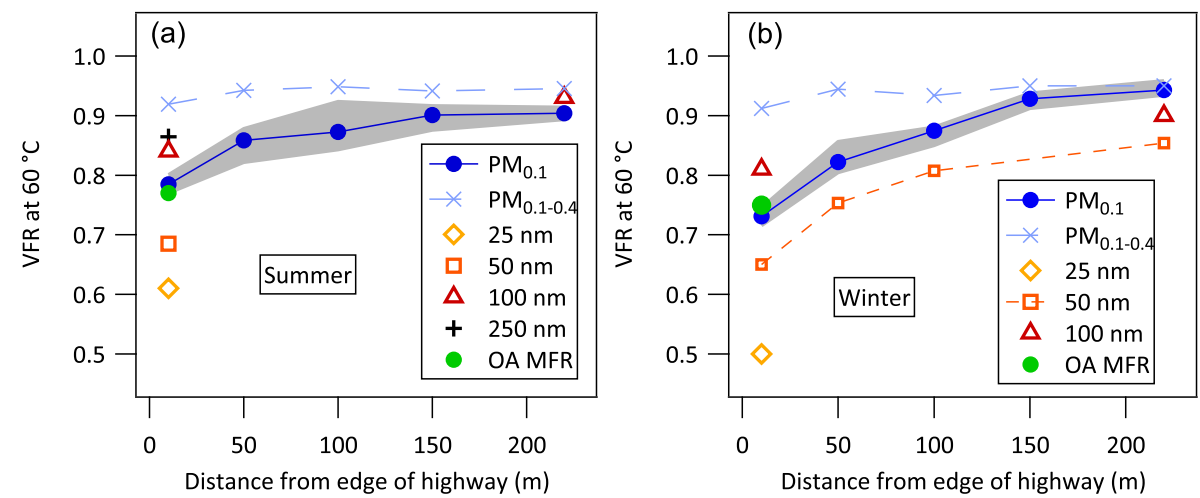

Figure 1. Campaign-average downwind evolution of volume fraction remaining (VFR) of near-road particles after heating at $60{ }^{\circ} \mathrm{C}$ in a TD $(\mathrm{Rt}=30 \mathrm{~s})$ during (a) summer and (b) winter. VFR of size-selected particles (e.g., 25, 50, 100, 250 nm) obtained from V-TDMA measurements. VFR of $\mathrm{PM}_{0.1}$ and $\mathrm{PM}_{0.1-0.4}$ estimated from integrated SMPS volume between 10 and $100 \mathrm{~nm}$ and between 100 and $400 \mathrm{~nm}$, respectively. OA MFR was measured using a TD-ACSM system $(\mathrm{Rt}=30 \mathrm{~s})$ in the near-road trailer. The shaded area represents the interquartile range of all measurements for each season.
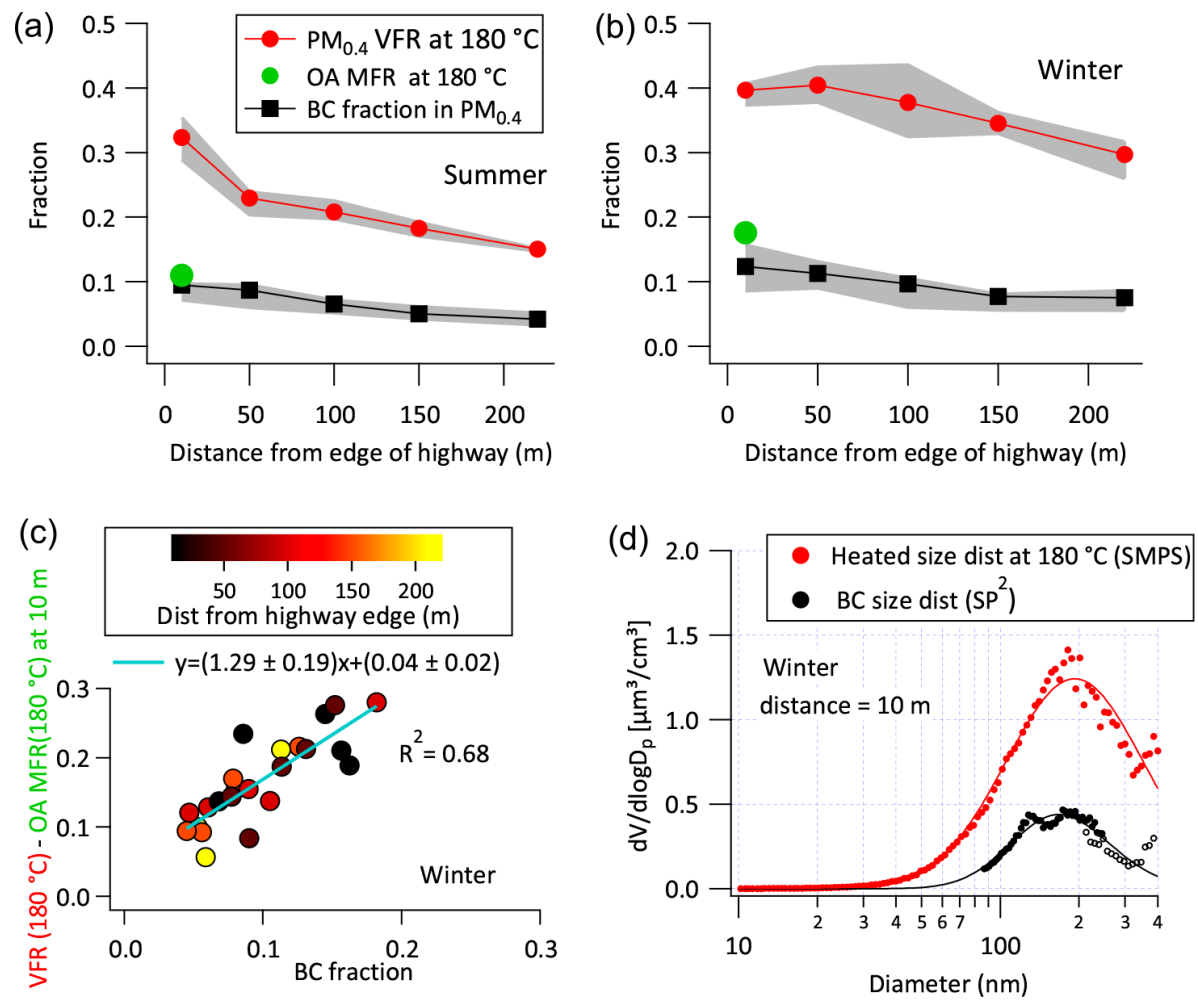

Figure 2. Campaign-average downwind evolution of volume fraction remaining (VFR) of $\mathrm{PM}_{0.4}$ (integrated SMPS volume over 10-400 nm) at $180^{\circ} \mathrm{C}$ in a $\mathrm{TD}(\mathrm{Rt}=30 \mathrm{~s})$ and black carbon $(\mathrm{BC})$ fraction in $\mathrm{PM}_{0.4}$ during (a) summer and (b) winter. Points are the mean and the shaded area represents the interquartile range. OA MFR was measured using a TD-ACSM system (Rt $=30 \mathrm{~s})$ only in the near-road trailer. (c) Correlation between the $\mathrm{BC}$ fraction and VFR of $\mathrm{PM}_{0.4}$ (at $180^{\circ} \mathrm{C}$ ) at various downwind distances after subtracting $\mathrm{OA}$ MFR (at $180{ }^{\circ} \mathrm{C}$ ) measured at $10 \mathrm{~m}$. (d) Comparison of SMPS-measured thermodenuded size distribution at $180^{\circ} \mathrm{C}$ and SP2-measured BC size distribution.

ent of VFR of $\mathrm{PM}_{0.4}$ at $180^{\circ} \mathrm{C}$ in winter. Figure $2 \mathrm{c}$ shows a scatter plot of the $\mathrm{BC}$ fraction in PM vs. VFR of $\mathrm{PM}_{0.4}$ (at $180^{\circ} \mathrm{C}$ ) after subtracting OA MFR (at $180^{\circ} \mathrm{C}$ ) measured at $10 \mathrm{~m}$ for the winter data set; a similar plot for the summer data set is shown in Fig. S6. These correlation analy- ses indicate that the observed downwind evolution of VFR at $180^{\circ} \mathrm{C}$ is likely dictated by the $\mathrm{BC}$ component of the aerosol. The $\mathrm{BC}$ fraction in this analysis was estimated as the ratio of the PAX-measured BC to PM mass concentration from integrated volume-weighted SMPS size distributions with an 
estimated effective density of $1.5 \mathrm{~g} \mathrm{~cm}^{-3}$. See Fig. S7 for details on the estimation of effective density and a comparison of submicron mass concentrations measured by SMPS and $\mathrm{ACSM}+\mathrm{PAX}$.

The diurnal profile of SP2-measured BC size distribution, shown in Fig. S8, indicates that BC is strongly correlated with the diurnal profile of traffic volume, indicating that vehicles are the major source of $\mathrm{BC}$ at this near-highway site. Figure $2 \mathrm{~d}$ explores the contribution of $\mathrm{BC}$ to the thermodenuded SMPS size distribution at $180^{\circ} \mathrm{C}$. In Fig. 2d, to directly compare with the volume-weighted SMPS distribution, the mass-weighted $\mathrm{BC}$ size distribution was converted to a volume-weighted distribution by assuming a $\mathrm{BC}$ density of $1.8 \mathrm{~g} \mathrm{~cm}^{-3}$. The BC distribution accounts for approximately $35 \%$ of the area under the thermodenuded particle size distribution at $180^{\circ} \mathrm{C}$ (Fig. 2d). The remaining approximately $65 \%$ of material should consist of different low-volatility species (e.g., ELVOCs and others). This is broadly consistent with the measured OA MFR at $180^{\circ} \mathrm{C}$ at the roadside trailer, which explained $\sim 50 \%$ of measured VFR at $180^{\circ} \mathrm{C}$ at that location (Fig. 2a and b). Therefore, by combining measurements from different instruments and approaches, the analysis summarized in Fig. 2 indicates that in a near-road environment, denuded particle volume at very high temperature (at $180^{\circ} \mathrm{C}$ ) can be approximated as $\sim$ ELVOCs $+\mathrm{BC}$, with a spatial distribution that is dictated by that of $\mathrm{BC}$.

\subsection{Mixing state of near-highway particles}

Figure 3 examines the mixing state of near-highway particles using V-TDMA data. The heated size distributions of a sizeselected monodisperse (at ambient temperature) aerosol at different TD temperatures are referred to as volatility spectra.

Figure 3 shows the measured average volatility spectra of 25,50 , and $100 \mathrm{~nm}$ particles collected $10 \mathrm{~m}$ from the highway during summer; similar winter observations are shown in Fig. S9. Heated monodisperse particles yield a bimodal size distribution; one mode (less volatile; LV mode) shows almost no change from its original diameter with heating, and the other mode (more volatile; MV mode) shrinks substantially with heating. Similar bimodal distributions have been observed in previous near-road studies (Biswas et al., 2007; Kuhn et al., 2005; Tiitta et al., 2010). The general trend was found to be consistent across seasons.

A large fraction of LV-mode particles is expected to be fresh soot from traffic emissions. Figure 3 suggests that LVmode particles are externally mixed (e.g., soot and OA exist in different particles) because if they were internally mixed with semi-volatile organics or others compounds (i.e., were coated), the coating material would evaporate with heating and a substantial diameter reduction would be observed. Several studies have shown that these LV-mode particles are less hygroscopic using a V-TDMA coupled with an H-TDMA system (Kuwata et al., 2007; Tiitta et al., 2010). The pres-
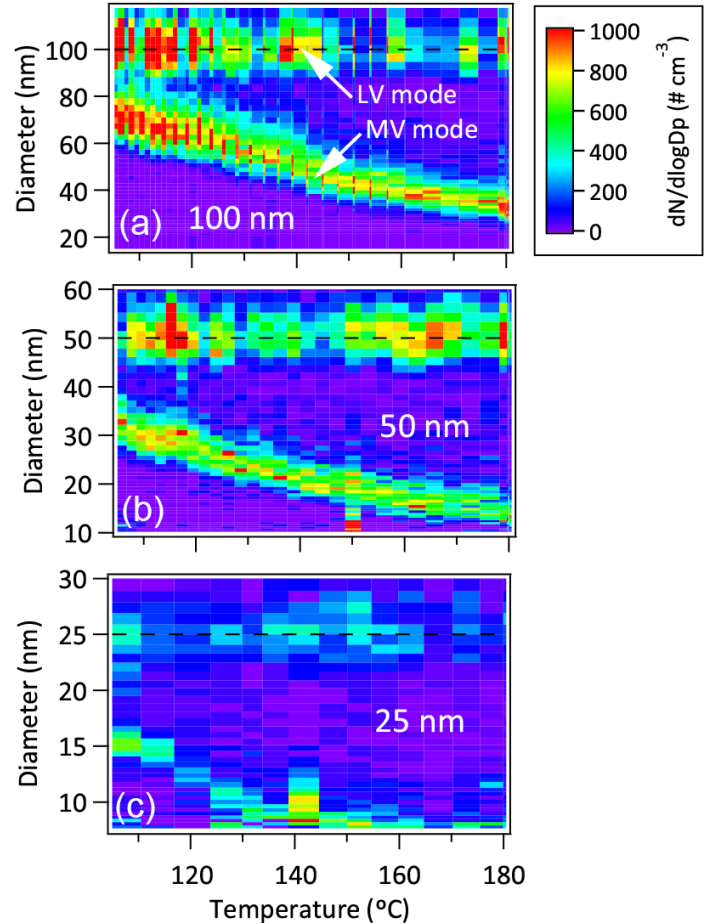

Figure 3. Campaign-average V-TDMA volatility spectra of (a) $100 \mathrm{~nm}$, (b) $50 \mathrm{~nm}$, and (c) $25 \mathrm{~nm}$ particles measured $10 \mathrm{~m}$ from the highway in summer. Figure S9 shows similar plots for the winter data set.

ence of externally mixed LV particles was observed for all sizes studied $(25,50,100$, and $250 \mathrm{~nm})$. However, the LV mode was relatively less pronounced for smaller sizes (e.g., $25 \mathrm{~nm}$ ) compared to larger particles (e.g., $100 \mathrm{~nm}$ ). The SP2measured BC number size distribution peaked around 100 $130 \mathrm{~nm}$ (see Figs. 2d and S8c), which is consistent with this observation. Kuhn et al. (2005) and Biswas et al. (2007) also reported that the less volatile and nonvolatile fraction of near-road aerosols increased with size within the size range studied (20-120 nm) in near-road V-TDMA measurements in California.

Figure 4 explores the mixing state of near-highway $\mathrm{BC}$ particles using the SP2 lag-time approach (Moteki and Kondo, 2007; Schwarz et al., 2006; Shiraiwa et al., 2007; Subramanian et al., 2010). The delay time between the occurrence of scattering and incandescence peaks observed in the SP2 can be used as an indicator of relative coating thickness ( $\Delta \tau=\tau_{\text {incandescence }}-\tau_{\text {scattering }}=$ time to "boil off" coating; McMeeking et al., 2011a; Moteki and Kondo, 2007). Figure 4 shows the frequency distributions (histograms) of delay time $(\Delta \tau)$. Following McMeeking et al. (2011a), the entire ensemble of refractory-BC-containing particles with scattering responses within the detection range was considered in this analysis. Measurements are stratified by wind direction to separate those measured during wind events coming off the highway (southwesterly; $225 \pm 45^{\circ}$ ) to the monitoring 
site and the opposite wind direction (northeasterly; $45 \pm 45^{\circ}$ ). Two distinct peaks near $\Delta \tau \sim 0.5$ and $\sim 3.5 \mu$ s appear in the $\Delta \tau$ frequency distribution. We use this to classify BC particles into two types using a threshold $\Delta \tau$ of $2 \mu$ s: thinly coated BC $(\Delta \tau<2 \mu \mathrm{s})$ and thickly coated BC $(\Delta \tau>2 \mu \mathrm{s})$. The threshold criterion is based on the observed minimum in the bimodal frequency distribution of $\Delta \tau$ (McMeeking et al., 2011a; Moteki and Kondo, 2007).

Figure 4 shows that a large fraction (up to $80 \%$ ) of rBC-containing particles at this near-highway site are thinly coated (externally mixed) and are likely fresh soot particles from traffic emissions. The observed relative proportion of thinly coated (fresh) particles increases when the wind comes off the highway to the monitoring station (southwesterly wind; see Fig. 4), suggesting that the local source (I-40 traffic) was the main contributor to this fraction. Using the data collected with the wind coming off the highway, Fig. S10 shows the linkage among the diurnal variation of $\Delta \tau$ frequency distributions, $\mathrm{BC}$ size distributions, and thermodenuded SMPS size distribution at $180^{\circ} \mathrm{C}$. The thinly coated fraction was found to be slightly higher in the midday and morning compared to the evening. This trend correlates with the diurnal variation of the heavy-duty vehicle (HDV) fraction (indicated in inset of Fig. S10), suggesting that HDVs are the dominant contributor to the observed fresh (thinly coated) $\mathrm{BC}$ fraction. The thickly coated fraction is likely contributed by regional background aged $\mathrm{BC}$ particles. However, approximately $10 \%$ of fresh BC from vehicular emissions could be thickly coated as reported by Willis et al. (2016). With an opposite wind (northeasterly), a minimum direct influence from I-40 traffic is expected at our monitoring location. The observed thickly coated fraction at that wind condition went up to $41 \%$. This range of values is consistent with past studies. For example, a thickly coated rBC fraction of approximately $30-40 \%$ is reported in previous measurements in diverse urban environments (McMeeking et al., 2011a; Shiraiwa et al., 2007; Subramanian et al., 2010).

The substantial presence of thinly coated (fresh) rBC suggested by the SP2 data (Fig. 4) is consistent with our independently measured V-TDMA observations of externally mixed characteristics for LV-mode particles (Figs. 3 and S9). These observations are also in agreement with several recent studies that examined the mixing state of rBC from traffic emissions using a range of techniques (China et al., 2014; Kuwata et al., 2009; Liu et al., 2014; McMeeking et al., 2011b; Willis et al., 2016). Willis et al. (2016) reported that approximately $90 \%$ of rBC mass resides in $\mathrm{rBC}$-rich particles using soot photometer-aerosol mass spectrometer (SP-AMS) measurements of traffic emissions in an urban setting, whereas the remaining $10 \%$ were mixed with hydrocarbon-like OA (HOA). China et al. (2014) reported that $\sim 72 \%$ of soot particles from vehicle exhaust are barely or thinly coated using a microscopic imaging technique. Traffic-dominated rBC particles were reported to be uncoated or very thinly coated by

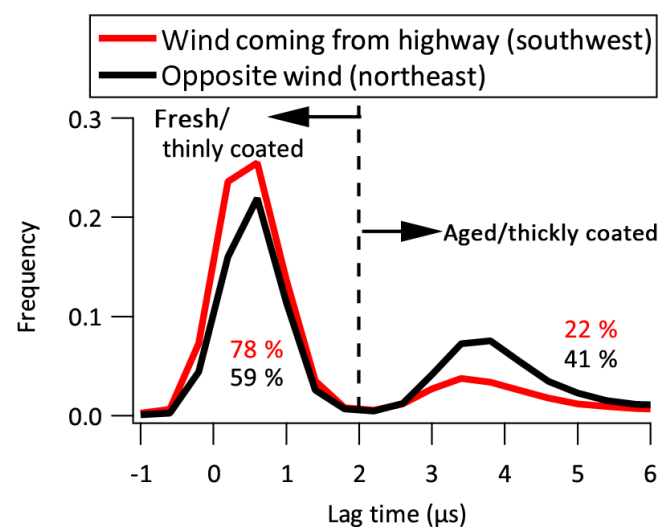

Figure 4. Campaign-average frequency distributions (histograms) of SP2 lag time $(\Delta \tau)$ for refractory-BC-containing particles measured during periods with winds from the highway (red) or from the opposite direction (black). Measurements were collected at a distance of $10 \mathrm{~m}$ from the highway in winter.

Laborde et al. (2013) and Liu et al. (2014) using SP2 measurements in urban environments.

Figure 5 compares V-TDMA measurements of $100 \mathrm{~nm}$ particles at different distances from the highway to examine the evolution of the mixing state of particles with downwind transport. The overall concentration of both LV- and MV-mode particles rapidly decreases with distance due to dilution and mixing with cleaner background air. However, LVmode particles (e.g., BC) remain mostly externally mixed at $220 \mathrm{~m}$ of downwind distance. This result indicates that there is minimal change in the mixing state in traffic-emitted particles between the near-road $(\sim 10 \mathrm{~m})$ and far-road $(\sim 220 \mathrm{~m})$ locations. Specifically, the proportion of internally vs. externally mixed particles does not appear to change, nor is there evidence of substantial coating on externally mixed "nonvolatile" particles. The evolution of BC mixing state is typically observed in the atmosphere with photochemical aging; externally mixed BC particles (thinly coated) become progressively internally mixed (thickly coated) via the formation of condensable vapors via photochemical processes followed by condensation on BC. Timescales on the order of $1 \mathrm{~h}$ are typically required to observe a significant change in BC coating (Adachi and Buseck, 2013; McMeeking et al., 2011a; Shiraiwa et al., 2007; Subramanian et al., 2010). Since the transport times of particles at $220 \mathrm{~m}$ downwind from the highway are on the order of a few seconds to minutes, it is not surprising to observe no significant change in the mixing state of traffic-emitted particles (e.g., BC) within this short distance.

\subsection{Inferred volatility distributions from TD data}

This section discusses TD-derived volatility distributions at different distances from the highway to provide insight into the evolution of the volatility of traffic-emitted particles and 

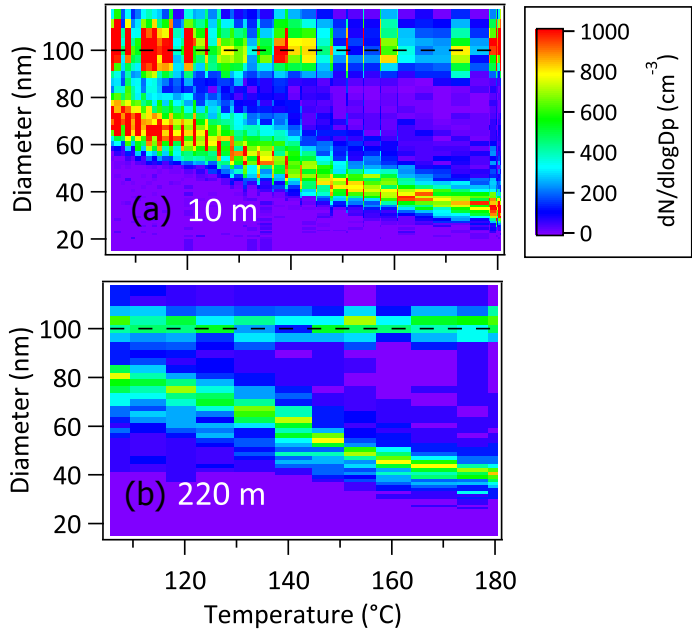

Figure 5. Similar to Fig. 3 showing average volatility spectra of $100 \mathrm{~nm}$ particles at 10 and $220 \mathrm{~m}$ downwind of the highway. Measurements were collected during transect runs in summer.

provide parameterizations to explain the phase partitioning of near-road particles in similar microenvironments and laboratory observations. For this, we focus on the measured evaporation of ultrafine particles $(25,50$, and $100 \mathrm{~nm})$ at 10 and $220 \mathrm{~m}$ distances. Figure 6 shows measured and modeled thermograms (plots of VFR vs. TD temperature) for TD measurements of varying particle sizes collected at different distances and seasons. At a particular TD temperature, smaller particles evaporate more than larger particles (Fig. 6). Size or composition (volatility distribution) may contribute to the differential evaporation observed for different size particles (Saleh et al., 2011); both factors were taken into account during evaporation kinetics modeling following the framework described in Saha et al. (2015). The evaporation kinetics model tracks changes in diameter as aerosols with prescribed properties pass through the TD at a particular operating condition ( $T, \mathrm{Rt}$ ), as described in Sect. 2.4; model VFR was estimated based on predicted change in particle diameter. In our fitting, we solved for particle volatility distributions (particle-phase distribution; $\{x\}_{i}$ ) via least-squares fitting of modeled and measured VFR. Fitted distributions are listed in Table S2 and model lines in Fig. 6 are shown using these best-fit distributions. Our fitting results (Fig. 6) show that at a particular downwind point, a single volatility distribution can explain the observed evaporations for different sized particles, suggesting that particles within this size range have a consistent volatility distribution or chemical signature. We also report $f_{i}$ distributions (Table 1) after converting our TD-derived particle-phase distributions $\left(x_{i}\right)$ to total (gas + particle) distributions $\left(f_{i}\right)$ under gas-particle equilibrium conditions and assuming a typical near-road OA loading of $\sim 5 \mu \mathrm{g} \mathrm{m}^{-3}$ (see Sect. S3 in the Supplement for details).

Figure 7 shows simplified representations of particle volatility distributions at roadside $(10 \mathrm{~m})$ and downwind
$(220 \mathrm{~m})$ locations across summer and winter seasons. In this figure, distributions of particle-phase material are shown in two broad volatility categories: extremely low + low volatility (ELVOC $+\mathrm{LVOC} ; C^{*}$ bins $\leq 0.1 \mu \mathrm{g} \mathrm{m}^{-3}$ ) and semivolatile (SVOC; $C^{*}$ bins $\geq 1 \mu \mathrm{g} \mathrm{m}^{-3}$; Donahue et al., 2012). A laboratory-derived POA volatility distribution of gasoline vehicle exhaust by May et al. (2013a; derived from chromatographic analyses of filter samples) is also shown under a typical near-road aerosol loading $\left(C_{\mathrm{OA}}=5 \mu \mathrm{g} \mathrm{m}^{-3}\right)$. The volatility distributions shown in Fig. 7 and also reported in Tables 1 and $\mathrm{S} 2$ are at a reference temperature of $25^{\circ} \mathrm{C}$, which allows for a convenient side-by-side comparison across seasons and with previous studies. The gasoline POA distribution by May et al. (2013a) places $\sim 45 \%$ of OA in the SVOC bins under this condition. Our TD-derived results show that the overall volatility of near-road particles is lower than laboratory-derived POA distribution, varies across seasons and decreases with distance. The extracted volatility distributions of near-road particles are a mixture of traffic-emitted POA and background particles. Therefore, it is not expected that the overall volatility of near-road particles would be the same as that of vehicle POA. In Sect. 3.4, we use our spatial measurements of near-road aerosol (traffic + background) volatility to assess how and whether this laboratory-derived POA distribution can be used to represent the overall near-road volatility under real-world conditions.

Figure 7 indicates that the overall volatility of near-road aerosols decreases with distance from the highway in both seasons. For example, the TD-derived distributions apportion approximately $20-30$ and $10 \%$ of particle-phase mass as SVOC at 10 and $220 \mathrm{~m}$, respectively, which is consistent with the dilution-driven evaporation of SVOCs and/or mixing with the background particles. When a volatility comparison is made at a common temperature of $25^{\circ} \mathrm{C}$ (Fig. 7), the particle volatility was found to be slightly higher for the winter data set than summer, especially closer to the highway. The extent of dilution and the temperature of dilution air dictate the overall partitioning of semi-volatile emissions. Atmospheric dilution was substantially lower in winter at our site (and generally) due to more stable atmospheric conditions under colder weather (Saha et al., 2018). Therefore, when comparing particle volatility at the same temperature, lower dilution during winter likely explains the observed higher SVOC fraction.

The volatility comparison in Fig. 7 is shown at a reference temperature of $25^{\circ} \mathrm{C}$; actual partitioning will vary with ambient temperature. Under a particular $C_{\mathrm{OA}}$ loading (atmospheric dilution), it is expected that a higher fraction of semivolatile material partitions into the particle phase at colder temperatures. Figure S11 is an alternate display of the data in Fig. 7, showing the volatility comparison at campaignaverage ambient temperatures of $\sim 5$ and $\sim 30^{\circ} \mathrm{C}$ in winter and summer, respectively. After accounting for seasonal temperature difference, Fig. S11 indicates that the particle-phase SVOC fractions are approximately 2.5 times higher in winter 

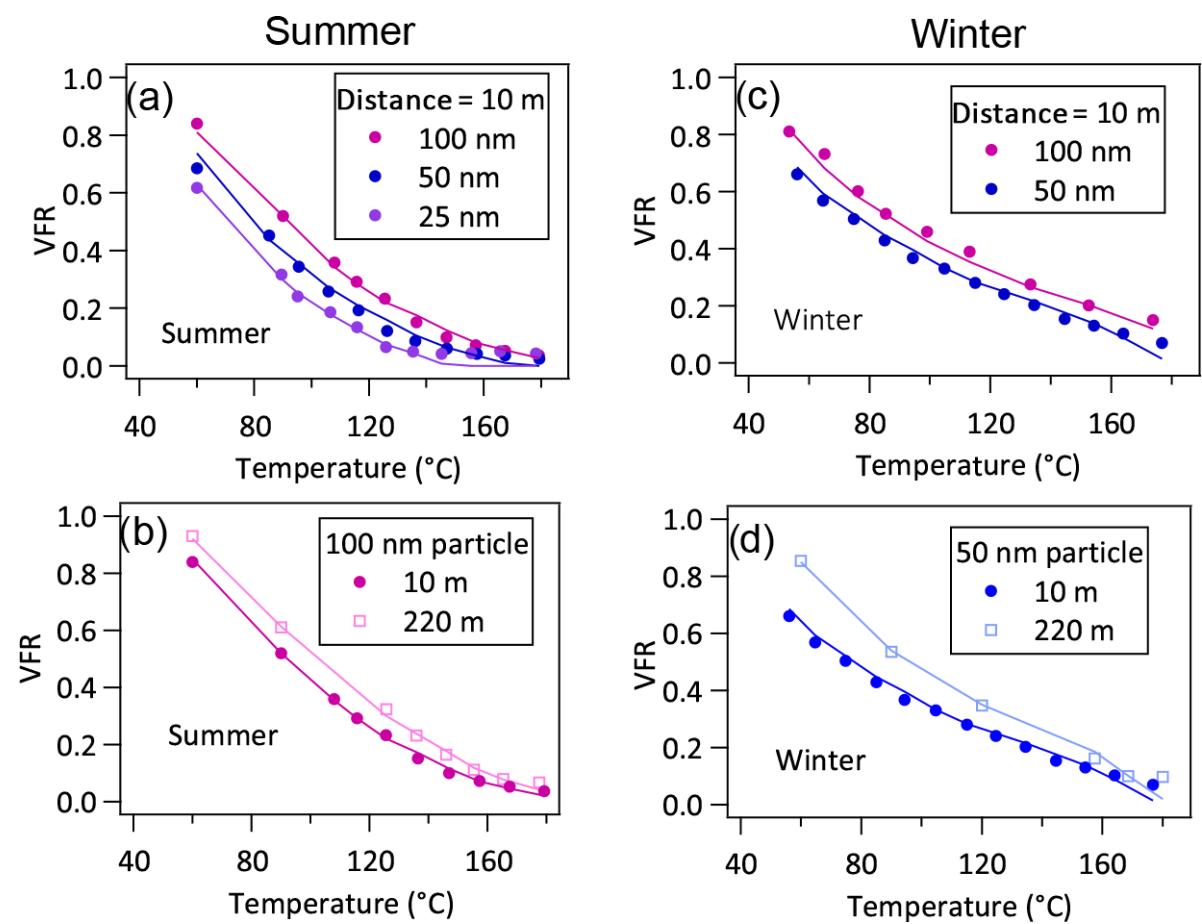

Figure 6. Campaign-average measured (points) and modeled (line) thermograms for different sized particles measured at 10 and $220 \mathrm{~m}$ downwind during summer (a-b) and winter (c-d). Model lines are shown using the best-fitted volatility distributions listed in Tables 1 and $\mathrm{S} 2 ; \Delta H_{\mathrm{vap}}=100 \mathrm{KJ} \mathrm{mol}^{-1}$ and $\gamma_{\mathrm{e}}=0.25$.

Table 1. TD-derived particle volatility distributions (at $298 \mathrm{~K}$ ) at 10 and $220 \mathrm{~m}$ of downwind distance from the highway I-40 during summer and winter. Laboratory-derived gasoline POA distribution by May et al. (2013a) is also listed.

\begin{tabular}{|c|c|c|c|c|c|}
\hline \multirow{2}{*}{$\begin{array}{l}\log C^{*} \\
\text { at } 298 \mathrm{~K}\end{array}$} & \multicolumn{4}{|c|}{ TD-derived $f_{i}$ distribution ${ }^{\mathrm{a}}$} & \multirow{2}{*}{$\begin{array}{l}\text { Gasoline POA } \\
\text { (May et al., 2013) }\end{array}$} \\
\hline & $10 \mathrm{~m}$ (summer) & $220 \mathrm{~m}$ (summer) & $10 \mathrm{~m}$ (winter) & $220 \mathrm{~m}$ (winter) & \\
\hline-4 & 0.07 & 0.10 & 0.18 & 0.28 & \\
\hline-3 & 0.13 & 0.21 & 0.07 & 0.08 & \\
\hline-2 & 0.16 & 0.20 & 0.14 & 0.20 & 0.14 \\
\hline-1 & 0.27 & 0.37 & 0.15 & 0.30 & 0.13 \\
\hline 0 & 0.12 & 0.06 & 0.27 & 0.09 & 0.15 \\
\hline 1 & 0.25 & 0.06 & 0.20 & 0.06 & 0.26 \\
\hline 2 & & & & & 0.15 \\
\hline 3 & & & & & 0.03 \\
\hline 4 & & & & & 0.03 \\
\hline 5 & & & & & 0.01 \\
\hline 6 & & & & & 0.11 \\
\hline
\end{tabular}

a TD-fitted particle-phase distributions $\left(x_{i}\right)$ with $\gamma_{\mathrm{e}}=0.25$ and $\Delta H_{\mathrm{vap}}=100 \mathrm{KJ} \mathrm{mol}^{-1}$ (reported in Table S2) are converted to total (gas + particle) distribution $\left(f_{i}\right)$ under gas-particle equilibrium conditions and assuming a total aerosol loading of $\sim 5 \mu \mathrm{g} \mathrm{m}^{-3}$ (conversion equations are given in S1, Sect. S3).

${ }^{\mathrm{b}}$ Chromatographic analysis

(SVOC: $45 \%$ ) than summer (SVOC: $18 \%$ ) at the roadside location $(10 \mathrm{~m})$. During winter, a higher fraction of semivolatile particles may form via homogeneous nucleation during a rapid cooling of vehicle exhaust under a lower ambient temperature (Kittelson et al., 2006). This fact was supported by our observed threefold increase in ultrafine particle and
HOA emission factors during winter compared to summer, as discussed in Saha et al. (2018). This result implies that human exposure to semi-volatile particles at a near-road location could vary substantially across seasons and would be more extreme in colder weather. 

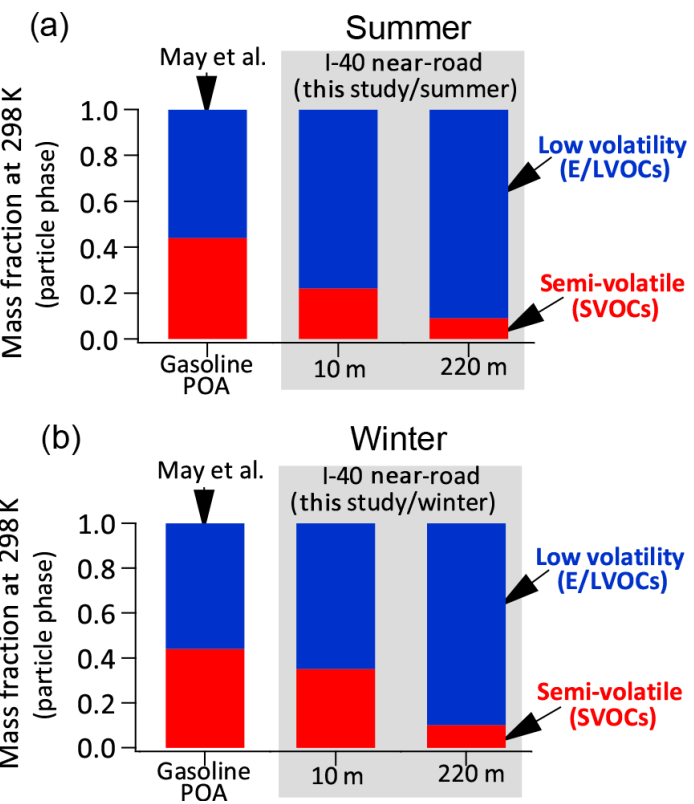

Figure 7. Comparison of volatility classification of near-road particles measured at 10 and $220 \mathrm{~m}$ (this study) for (a) summer and (b) winter at a reference temperature of $25^{\circ} \mathrm{C}$. Distributions of particlephase material are shown using two broad volatility categories. Also shown in both panels is the POA distribution from gasoline vehicle exhaust by May et al. (2013a) under typical near-road aerosol loading $\left(C_{\mathrm{OA}} \sim 5 \mu \mathrm{g} \mathrm{m}^{-3}\right)$.

\subsection{Evaluation of laboratory-derived POA distributions to explain roadside partitioning}

Particle mass concentrations measured next to a highway are a mixture of a traffic contribution and background particles (roadside $\mathrm{PM}=$ traffic + background). It can be reasonably hypothesized that the volatility distribution of roadside particles at a particular downwind location is a superposition of that from background particles and traffic-contributed particles at that location (Eq. 1). One can test this hypothesis if the volatility distributions of different populations of particles (roadside, background, traffic) are known. Vehicle-emitted POA volatility distributions have been derived in laboratory studies (May et al., 2013a, b) of a relatively small number of vehicles in controlled tests; they have also recently been measured in a traffic tunnel study (Li et al., 2016). Here, we used our spatial measurements of particle volatility distributions along with a laboratory-derived POA distribution from May et al. (2013a) to assess our ability to represent the volatility of POA from the overall traffic fleet in a complex near-road microenvironment.

$$
\begin{aligned}
& C_{\mathrm{OA}, \text { roadside }} \times x_{i, \text { roadside }}=C_{\mathrm{OA}, \text { traffic }} \times x_{i, \text { traffic }} \\
& +C_{\mathrm{OA}, \text { background }} \times x_{i, \text { background }}
\end{aligned}
$$

$C_{\mathrm{OA}}\left(\mu \mathrm{g} \mathrm{m}^{-3}\right)$ is the organic aerosol (OA) mass concentration, and $x_{i}$ is the distribution of OA mass concentrations at different volatility bins, following the volatility basis set (VBS) approach (Donahue et al., 2006).

To test Eq. (1), we conducted an analysis using an example data set from a morning transect on 12 June 2015 (summer), with the wind consistently coming off the highway; the details of the analysis are given in the Supplement, Sect. S4. Analysis results are shown in Fig. 8. The contribution of traffic particles in roadside measurements was estimated as the difference between concentrations measured at the roadside (downwind) and upwind background location. Figure 8a shows the measured upwind (background) and downwind OA mass concentrations as a function of distances from the highway. It should be noted here that approximate estimates of OA mass concentrations in Fig. 8a are calculated from integrated volume from SMPS measurements and an estimated effective density of $1.5 \mathrm{~g} \mathrm{~cm}^{-3}$ (Fig. S7) and subtracting the contribution of $\mathrm{BC}$ (as a function of distance), nitrate, and sulfate aerosols (measured by an ACSM at the near-road fixed-site trailer).

Figure $8 \mathrm{~b}$ compares our measured roadside volatility distribution (at $10 \mathrm{~m}$ ) with a distribution reconstructed from traffic and background distributions. Distributions of particlephase-only OA concentrations are shown. In this analysis, the volatility distribution of POA emissions from gasoline vehicle exhaust from May et al. (2013a; Table 1) is assumed to be representative of the overall traffic-emitted OA. Since we did not measure particle volatility at our upwind background site, we assume that the volatility distribution measured at our farthest downwind location $(220 \mathrm{~m})$ is a representative distribution for background particles. This is a reasonable approximation as particle concentrations approach background levels within $200-300 \mathrm{~m}$ from the highway (Saha et al., 2018). It should be noted that this "background" OA contains a non-negligible $(\sim 25 \%)$ contribution from traffic emissions (Fig. 8a), and so likely has a slightly greater contribution from higher-volatility components than what would be measured in an actual background location. Our measured distributions from the summer campaign (Table 1) were used to be consistent with the OA concentration measurements in this particular example. Overall, a good agreement was found between the measured distribution at $10 \mathrm{~m}$ downwind and superimposed distribution of background + traffic POA (Fig. 8b). In particular, the contribution from more volatile materials $\left(C^{*}=1\right.$ and $\left.10 \mu \mathrm{g} \mathrm{m}^{-3}\right)$ from traffic POA is required to explain the greater contribution from these more volatile species at $10 \mathrm{~m}$ vs. $220 \mathrm{~m}$ from the roadway. Therefore, this analysis indicates that the laboratory-derived volatility distribution from May et al. (2013a) can do a reasonably good job in explaining the observed partitioning of vehicle emissions in a complex near-road environment. In addition to the analysis in Fig. 8b, a similar analysis is shown in Fig. S12 using the "coarse" tracer $m / z$-based factor analysis approach to decompose OA mass spectra (Ng et al., 2011) in which the hydrocarbon-like OA (HOA) factor is assumed to represent traffic-sourced OA, and oxygenated OA (OOA) 

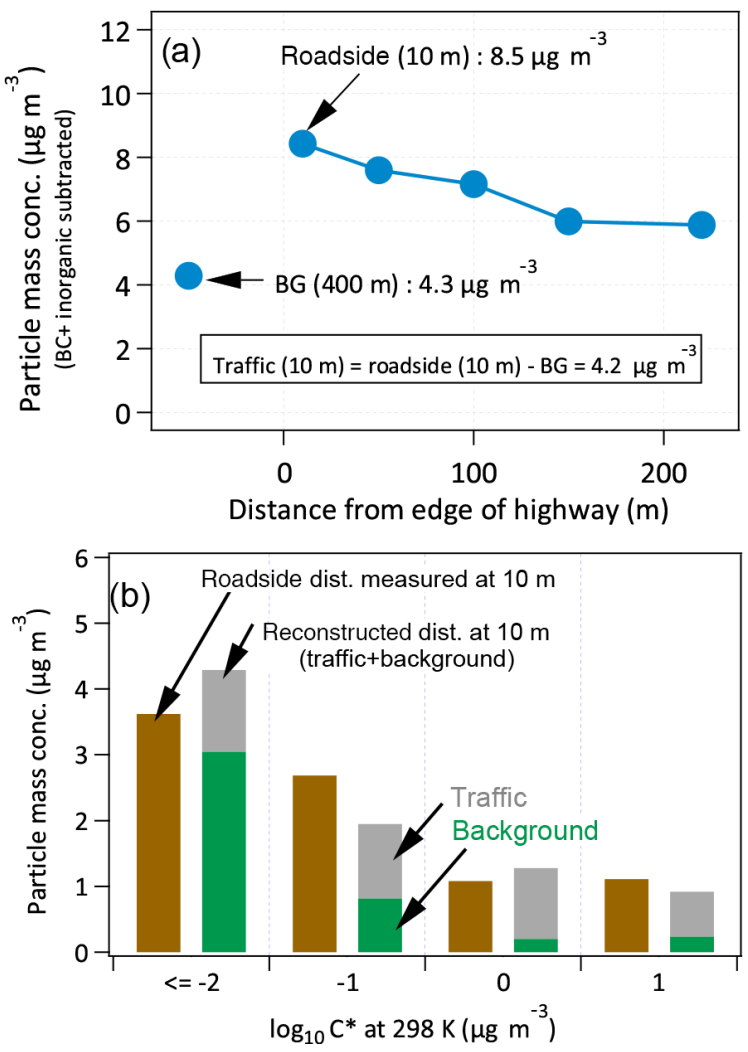

Figure 8. Comparison of measured roadside volatility distribution (at $10 \mathrm{~m}$ ) with a reconstructed distribution using traffic and background contributions. Analysis conducted using an example data set from a transect measurement on 12 June 2015 (summer), with the wind consistently coming off the highway. (a) Measured upwind (background) and downwind concentrations of particle mass loading as a function of distances from the highway. (b) Comparison of measured roadside volatility distribution (at $10 \mathrm{~m}$ ) with the reconstructed distribution using laboratory-measured POA volatility distribution from May et al. (2013a) as representative of traffic particles and our measured volatility distribution at our most downwind location $(220 \mathrm{~m})$ as representative of background particles.

is assumed to represent background OA. The details of this analysis are discussed in the Supplement, Sect. S5. While this simplified "superposition" analysis suggests that our data are able to capture the influences of near-road evolution on emissions, further measurements and modeling work are needed to represent these dynamic processes.

\section{Conclusions and implications}

Field experiments were conducted across two seasons in an effort to explore the evolution of the volatility and mixing state of near-road particles within a few hundred meters downwind of a highway. The spatial distributions of the volatility of near-road aerosols varied with distance from the highway and season. The overall volatility of near-road par- ticles decreases with distance from the roadway. For example, at a reference temperature of $25^{\circ} \mathrm{C}$, while approximately $20-30 \%$ of particle mass was classified as semi-volatile (SVOCs; $C^{*} \geq 1 \mu \mathrm{g} \mathrm{m}^{-3}$ ) $10 \mathrm{~m}$ from the roadway, only $\sim$ $10 \%$ of particle mass was attributed to semi-volatiles at $220 \mathrm{~m}$. The decrease in the semi-volatile fraction in the particle phase with downwind distance is likely due to dilutiondriven evaporation of SVOCs as fresh vehicle-emitted particles are transported downwind and/or mix with background particles. The relative abundance of semi-volatile material in the particle phase increased during winter, especially closer to the highway, reflecting the effect of temperature on semivolatile partitioning. The nonvolatile fraction in roadside aerosols appeared to be mostly externally mixed, and their mixing state showed minimal change within a few hundred meters from the highway.

This research has several important implications for the measurement and modeling of emissions and exposure to ultrafine particles (UFPs) in a near-road microenvironment and its regulation. First, the measured particle number (PN) concentrations in near-road settings are dominated by UFPs. In a companion paper (Saha et al., 2018), we showed that UFP number emission factors are substantially higher and their dispersion is slower during winter, indicating that human exposure to UFPs would be significantly higher in colder conditions. This paper shows that a significant fraction of UFPs is semi-volatile in nature, and hence a larger portion of semi-volatile materials likely exists in the particle phase in colder conditions. Current European vehicle particle number emission standards use measurements of thermally treated exhaust that strips the semi-volatile particle components to constrain variability among measurement approaches (Wang et al., 2017). As a result, this regulatory measurement likely does not address the seasonally and spatially varying realworld particle number concentrations and compositions to which people are exposed. Several recent toxicology studies (Biswas et al., 2009; Keebaugh et al., 2015) reported that the semi-volatile species in traffic-sourced particles could be more toxic than less volatile components. Therefore, our observed seasonal variation in UFP emission factors and semivolatile components in the particle phase suggest that human exposure to UFPs and their toxicity in a near-road microenvironment could vary with seasons and environmental conditions and would be more extreme in colder weather. The elevated fraction of semi-volatile materials in roadside particles and their potentially higher toxicity suggest that an equivalent amount of exposure (concentration $\times$ duration) to roadside vs. background particles could have significantly different health impacts. However, the toxicity of different volatility and size classes of PM is not well established in the current literature. For example, Cho et al. (2009) reported no significant difference in the overall toxicity end points for PM samples collected at 20 and $275 \mathrm{~m}$ from an interstate highway. Further research is needed to better understand the toxicity and health impacts of different volatility and size 
classes of PM from different sources and environmental conditions. Second, our finding of externally mixed near-road particles suggests that exposure to $\mathrm{BC}$ - and $\mathrm{OA}$-containing particles could be different across seasons. For example, OA-containing particles will be more dynamic under changing ambient conditions. Environmental conditions (temperature, atmospheric dilution) will influence the gas-particle partitioning of SVOCs and thus exposure to condensed- vs. vapor-phase SVOC under changing ambient conditions. On the other hand, exposure to $\mathrm{BC}$ would be less influenced by changing ambient conditions. Finally, the volatility distributions and mixing state characteristics of near-road particles derived here can be used to examine the representativeness of laboratory-derived results in a complex real-world scenario (as shown via an example in this paper) and to improve the representation of traffic-sourced aerosols in air quality, exposure assessment, and chemical transport models.

Data availability. Final data archiving was not complete upon publication of this paper. However, all data used for this study are available upon request to the corresponding author (apgriesh@ncsu.edu).

\section{The Supplement related to this article is available online at https://doi.org/10.5194/acp-18-2139-2018-supplement.}

Competing interests. The authors declare that they have no conflict of interest.

Acknowledgements. We thank Sue Kimbrough, Rich Baldauf, and Richard Snow of the US EPA Office of Research and Development, Research Triangle Park (RTP), NC for help and support with establishing the roadside trailer facility for this study. We thank Steve Weiandt (Atlantic Investment Management) for providing access and support with establishing the background site for this study. We thank Nagui Rouphail and his research group (NCSU) and NC-DOT for the traffic data used in this paper.

Funding was provided by the Health Effects Institute (HEI) under RFA 13-1. The contents of this paper are solely the responsibility of the authors and do not necessarily represent the official views of HEI, and no official endorsement should be inferred.

Edited by: Annele Virtanen

Reviewed by: two anonymous referees

\section{References}

Adachi, K. and Buseck, P. R.: Changes of ns-soot mixing states and shapes in an urban area during CalNex, J. Geophys. Res.-Atmos., 118, 3723-3730, https://doi.org/10.1002/jgrd.50321, 2013.
Baldauf, R., Thoma, E., Hays, M., Shores, R., Kinsey, J., Gullett, B., Kimbrough, S., Isakov, V., Long, T., Snow, R., Khlystov, A., Weinstein, J., Chen, F.-L., Seila, R., Olson, D., Gilmour, I., Cho, S.H., Watkins, N., Rowley, P., and Bang, J.: Traffic and meteorological impacts on near-road air quality: summary of methods and trends from the Raleigh Near-Road Study, J. Air Waste Manage., 58, 865-878, https://doi.org/10.3155/1047-3289.58.7.865, 2008.

Biswas, S., Ntziachristos, L., Moore, K. F., and Sioutas, C.: Particle volatility in the vicinity of a freeway with heavyduty diesel traffic, Atmos. Environ., 41, 3479-3493, https://doi.org/10.1016/j.atmosenv.2006.11.059, 2007.

Biswas, S., Verma, V., Schauer, J. J., Cassee, F. R., Cho, A. K., and Sioutas, C.: Oxidative Potential of Semi-Volatile and Non Volatile Particulate Matter (PM) from Heavy-Duty Vehicles Retrofitted with Emission Control Technologies, Environ. Sci. Technol., 43, 3905-3912, https://doi.org/10.1021/es9000592, 2009.

Bond, T. C., Doherty, S. J., Fahey, D. W., Forster, P. M., Berntsen, T., DeAngelo, B. J., Flanner, M. G., Ghan, S., Kärcher, B., Koch, D., Kinne, S., Kondo, Y., Quinn, P. K., Sarofim, M. C., Schultz, M. G., Schulz, M., Venkataraman, C., Zhang, H., Zhang, S., Bellouin, N., Guttikunda, S. K., Hopke, P. K., Jacobson, M. Z., Kaiser, J. W., Klimont, Z., Lohmann, U., Schwarz, J. P., Shindell, D., Storelvmo, T., Warren, S. G., and Zender, C. S.: Bounding the role of black carbon in the climate system: a scientific assessment, J. Geophys. Res.Atmos., 118, 5380-5552, https://doi.org/10.1002/jgrd.50171, 2013.

Broday, D. M. and Rosenzweig, R.: Deposition of fractal-like soot aggregates in the human respiratory tract, J. Aerosol Sci., 42, 372-386, https://doi.org/10.1016/j.jaerosci.2011.03.001, 2011.

Cappa, C. D. and Jimenez, J. L.: Quantitative estimates of the volatility of ambient organic aerosol, Atmos. Chem. Phys., 10, 5409-5424, https://doi.org/10.5194/acp-10-5409-2010, 2010.

Cappa, C. D., Onasch, T. B., Massoli, P., Worsnop, D. R., Bates, T. S., Cross, E. S., Davidovits, P., Hakala, J., Hayden, K. L., Jobson, B. T., Kolesar, K. R., Lack, D. A., Lerner, B. M., Li, S.-M., Mellon, D., Nuaaman, I., Olfert, J. S., Petäjä, T., Quinn, P. K., Song, C., Subramanian, R., Williams, E. J., and Zaveri, R. A.: Radiative absorption enhancements due to the mixing state of atmospheric black carbon, Science, 337, 1078-1081, https://doi.org/10.1126/science.1223447, 2012.

China, S., Salvadori, N., and Mazzoleni, C.: Effect of traffic and driving characteristics on morphology of atmospheric soot particles at freeway on-ramps, Environ. Sci. Technol., 48, 3128-3135, https://doi.org/10.1021/es405178n, 2014.

Cho, S.-H., Tong, H., McGee, J. K., Baldauf, R. W., Krantz, Q. T., and Gilmour, M. I.: Comparative Toxicity of Size-Fractionated Airborne Particulate Matter Collected at Different Distances from an Urban Highway, Environ. Health Perspect., 117, 16821689, https://doi.org/10.1289/ehp.0900730, 2009.

Choi, W. and Paulson, S. E.: Closing the ultrafine particle number concentration budget at road-to-ambient scale: implications for particle dynamics, Aerosol Sci. Tech., 50, 448-461, https://doi.org/10.1080/02786826.2016.1155104, 2016. 
Dallmann, T. R. and Harley, R. A.: Evaluation of mobile source emission trends in the United States, J. Geophys. Res.-Atmos., 115, D14305, https://doi.org/10.1029/2010JD013862, 2010.

Dallmann, T. R., Onasch, T. B., Kirchstetter, T. W., Worton, D. R., Fortner, E. C., Herndon, S. C., Wood, E. C., Franklin, J. P., Worsnop, D. R., Goldstein, A. H., and Harley, R. A.: Characterization of particulate matter emissions from on-road gasoline and diesel vehicles using a soot particle aerosol mass spectrometer, Atmos. Chem. Phys., 14, 7585-7599, https://doi.org/10.5194/acp-14-7585-2014, 2014.

DeWitt, H. L., Hellebust, S., Temime-Roussel, B., Ravier, S., Polo, L., Jacob, V., Buisson, C., Charron, A., André, M., Pasquier, A., Besombes, J. L., Jaffrezo, J. L., Wortham, H., and Marchand, N.: Near-highway aerosol and gas-phase measurements in a high-diesel environment, Atmos. Chem. Phys., 15, 4373-4387, https://doi.org/10.5194/acp-15-4373-2015, 2015.

Donahue, N. M., Robinson, A. L., Stanier, C. O., and Pandis, S. N.: Coupled partitioning, dilution, and chemical aging of semivolatile organics, Environ. Sci. Technol., 40, 2635-2643, https://doi.org/10.1021/es052297c, 2006.

Donahue, N. M., Kroll, J. H., Pandis, S. N., and Robinson, A. L.: A two-dimensional volatility basis set - Part 2: Diagnostics of organic-aerosol evolution, Atmos. Chem. Phys., 12, 615-634, https://doi.org/10.5194/acp-12-615-2012, 2012.

Ehn, M., Thornton, J. A., Kleist, E., Sipilä, M., Junninen, H., Pullinen, I., Springer, M., Rubach, F., Tillmann, R., Lee, B., Lopez-Hilfiker, F., Andres, S., Acir, I.-H., Rissanen, M., Jokinen, T., Schobesberger, S., Kangasluoma, J., Kontkanen, J., Nieminen, T., Kurtén, T., Nielsen, L. B., Jørgensen, S., Kjaergaard, H. G., Canagaratna, M., Maso, M. D., Berndt, T., Petäjä, T., Wahner, A., Kerminen, V.-M., Kulmala, M., Worsnop, D. R., Wildt, J., and Mentel, T. F.: A large source of low-volatility secondary organic aerosol, Nature, 506, 476-479, https://doi.org/10.1038/nature13032, 2014.

Epstein, S. A., Riipinen, I., and Donahue, N. M.: A semiempirical correlation between enthalpy of vaporization and saturation concentration for organic aerosol, Environ. Sci. Technol., 44, 743748, https://doi.org/10.1021/es902497z, 2010.

Fraser, M. P., Cass, G. R., and Simoneit, B. R. T.: Particulate organic compounds emitted from motor vehicle exhaust and in the urban atmosphere, Atmos. Environ., 33, 2715-2724, https://doi.org/10.1016/S1352-2310(98)00311-2, 1999.

Grieshop, A. P., Miracolo, M. A., Donahue, N. M., and Robinson, A. L.: Constraining the volatility distribution and gasparticle partitioning of combustion aerosols using isothermal dilution and thermodenuder measurements, Environ. Sci. Technol., 43, 4750-4756, https://doi.org/10.1021/es8032378, 2009.

Health Effects Institute: Traffic-related air pollution: a critical review of the literature on emissions, exposure, and health effects, Health Eff. Inst., https://www.healtheffects.org/publication/traffic-related-airpollution-critical-review-literature-emissions-exposure-andhealth, last access: 4 January 2017, 2010.

Hoek, G., Boogaard, H., Knol, A., de Hartog, J., Slottje, P., Ayres, J. G., Borm, P., Brunekreef, B., Donaldson, K., Forastiere, F., Holgate, S., Kreyling, W. G., Nemery, B., Pekkanen, J., Stone, V., Wichmann, H.-E., and van der Sluijs, J.: Concentration response functions for ultrafine particles and allcause mortality and hospital admissions: results of a european expert panel elicitation, Environ. Sci. Technol., 44, 476-482, https://doi.org/10.1021/es9021393, 2009.

Huffman, J. A., Ziemann, P. J., Jayne, J. T., Worsnop, D. R., and Jimenez, J. L.: Development and characterization of a fast-stepping/scanning thermodenuder for chemically-resolved aerosol volatility measurements, Aerosol Sci. Tech., 42, 395407, https://doi.org/10.1080/02786820802104981, 2008.

Jokinen, T., Berndt, T., Makkonen, R., Kerminen, V.-M., Junninen, H., Paasonen, P., Stratmann, F., Herrmann, H., Guenther, A. B., Worsnop, D. R., Kulmala, M., Ehn, M., and Sipilä, M.: Production of extremely low volatile organic compounds from biogenic emissions: measured yields and atmospheric implications, P. Natl. Acad. Sci. USA, 112, 7123-7128, https://doi.org/10.1073/pnas.1423977112, 2015.

Karner, A. A., Eisinger, D. S., and Niemeier, D. A.: Nearroadway air quality: synthesizing the findings from real-world data, Environ. Sci. Technol., 44, 5334-5344, https://doi.org/10.1021/es100008x, 2010.

Keebaugh, A. J., Sioutas, C., Pakbin, P., Schauer, J. J., Mendez, L. B., and Kleinman, M. T.: Is atherosclerotic disease associated with organic components of ambient fine particles?, Sci. Total Environ., 533, 69-75, https://doi.org/10.1016/j.scitotenv.2015.06.048, 2015.

Kittelson, D. B., Watts, W. F., and Johnson, J. P.: On-road and laboratory evaluation of combustion aerosols - Part1: Summary of diesel engine results, J. Aerosol Sci., 37, 913-930, https://doi.org/10.1016/j.jaerosci.2005.08.005, 2006.

Kleeman, M. J., Schauer, J. J., and Cass, G. R.: Size and composition distribution of fine particulate matter emitted from motor vehicles, Environ. Sci. Technol., 34, 1132-1142, https://doi.org/10.1021/es981276y, 2000.

Kuhn, T., Biswas, S., and Sioutas, C.: Diurnal and seasonal characteristics of particle volatility and chemical composition in the vicinity of a light-duty vehicle freeway, Atmos. Environ., 39, 7154-7166, https://doi.org/10.1016/j.atmosenv.2005.08.025, 2005.

Kumar, P., Ketzel, M., Vardoulakis, S., Pirjola, L., and Britter, R.: Dynamics and dispersion modelling of nanoparticles from road traffic in the urban atmospheric environment - a review, J. Aerosol Sci., 42, 580-603, https://doi.org/10.1016/j.jaerosci.2011.06.001, 2011.

Kuwata, M., Kondo, Y., Mochida, M., Takegawa, N., and Kawamura, K.: Dependence of CCN activity of less volatile particles on the amount of coating observed in Tokyo, J. Geophys. Res.Atmos., 112, D11207, https://doi.org/10.1029/2006JD007758, 2007.

Kuwata, M., Kondo, Y., and Takegawa, N.: Critical condensed mass for activation of black carbon as cloud condensation nuclei in Tokyo, J. Geophys. Res.-Atmos., 114, D20202, https://doi.org/10.1029/2009JD012086, 2009.

Kuwayama, T., Collier, S., Forestieri, S., Brady, J. M., Bertram, T. H., Cappa, C. D., Zhang, Q., and Kleeman, M. J.: Volatility of Primary Organic Aerosol Emitted from Light Duty Gasoline Vehicles, Environ. Sci. Technol., 49, 1569-1577, https://doi.org/10.1021/es504009w, 2015.

Laborde, M., Crippa, M., Tritscher, T., Jurányi, Z., Decarlo, P. F., Temime-Roussel, B., Marchand, N., Eckhardt, S., Stohl, A., Baltensperger, U., Prévôt, A. S. H., Weingartner, E., and Gysel, M.: Black carbon physical properties and mixing state in the 
European megacity Paris, Atmos. Chem. Phys., 13, 5831-5856, https://doi.org/10.5194/acp-13-5831-2013, 2013.

Lee, B. H., Kostenidou, E., Hildebrandt, L., Riipinen, I., Engelhart, G. J., Mohr, C., DeCarlo, P. F., Mihalopoulos, N., Prevot, A. S. H., Baltensperger, U., and Pandis, S. N.: Measurement of the ambient organic aerosol volatility distribution: application during the Finokalia Aerosol Measurement Experiment (FAME-2008), Atmos. Chem. Phys., 10, 12149-12160, https://doi.org/10.5194/acp-10-12149-2010, 2010.

Lee, B.-H., Pierce, J. R., Engelhart, G. J., and Pandis, S. N.: Volatility of secondary organic aerosol from the ozonolysis of monoterpenes, Atmos. Environ., 45, 2443-2452, https://doi.org/10.1016/j.atmosenv.2011.02.004, 2011.

Li, X., Dallmann, T. R., May, A. A., Tkacik, D. S., Lambe, A. T., Jayne, J. T., Croteau, P. L., and Presto, A. A.: Gas-particle partitioning of vehicle emitted primary organic aerosol measured in a traffic tunnel, Environ. Sci. Technol., 50, 12146-12155, https://doi.org/10.1021/acs.est.6b01666, 2016.

Liu, D., Allan, J. D., Young, D. E., Coe, H., Beddows, D., Fleming, Z. L., Flynn, M. J., Gallagher, M. W., Harrison, R. M., Lee, J., Prevot, A. S. H., Taylor, J. W., Yin, J., Williams, P. I., and Zotter, P.: Size distribution, mixing state and source apportionment of black carbon aerosol in London during wintertime, Atmos. Chem. Phys., 14, 10061-10084, https://doi.org/10.5194/acp-1410061-2014, 2014.

Matti Maricq, M.: Chemical characterization of particulate emissions from diesel engines: a review, J. Aerosol Sci., 38, 10791118, https://doi.org/10.1016/j.jaerosci.2007.08.001, 2007.

May, A. A., Presto, A. A., Hennigan, C. J., Nguyen, N. T., Gordon, T. D., and Robinson, A. L.: Gas-particle partitioning of primary organic aerosol emissions: (1) gasoline vehicle exhaust, Atmos. Environ., 77, 128-139, https://doi.org/10.1016/j.atmosenv.2013.04.060, 2013a.

May, A. A., Presto, A. A., Hennigan, C. J., Nguyen, N. T., Gordon, T. D., and Robinson, A. L.: Gas-particle partitioning of primary organic aerosol emissions: (2) diesel vehicles, Environ. Sci. Technol., 47, 8288-8296, https://doi.org/10.1021/es400782j, 2013b.

May, A. A., Levin, E. J. T., Hennigan, C. J., Riipinen, I., Lee, T., Collett, J. L., Jimenez, J. L., Kreidenweis, S. M., and Robinson, A. L.: Gas-particle partitioning of primary organic aerosol emissions: 3. Biomass burning, J. Geophys. Res.-Atmos., 118, 2013JD020286, https://doi.org/10.1002/jgrd.50828, 2013c.

McMeeking, G. R., Morgan, W. T., Flynn, M., Highwood, E. J., Turnbull, K., Haywood, J., and Coe, H.: Black carbon aerosol mixing state, organic aerosols and aerosol optical properties over the United Kingdom, Atmos. Chem. Phys., 11, 9037-9052, https://doi.org/10.5194/acp-11-9037-2011, 2011a.

McMeeking, G. R., Good, N., Petters, M. D., McFiggans, G., and Coe, H.: Influences on the fraction of hydrophobic and hydrophilic black carbon in the atmosphere, Atmos. Chem. Phys., 11, 5099-5112, https://doi.org/10.5194/acp-115099-2011, 2011b.

Moteki, N. and Kondo, Y.: Effects of mixing state on black carbon measurements by laser-induced incandescence, Aerosol Sci. Tech., 41, 398-417, https://doi.org/10.1080/02786820701199728, 2007.

Ng, N. L., Canagaratna, M. R., Jimenez, J. L., Zhang, Q., Ulbrich, I. M., and Worsnop, D. R.: Real-time methods for es- timating organic component mass concentrations from aerosol mass spectrometer data, Environ. Sci. Technol., 45, 910-916, https://doi.org/10.1021/es102951k, 2011.

Pankow, J. F.: An absorption model of gas/particle partitioning of organic compounds in the atmosphere, Atmos. Environ., 28 , 185-188, https://doi.org/10.1016/1352-2310(94)90093-0, 1994.

Pope, C. A. and Dockery, D. W.: Health effects of fine particulate air pollution: lines that connect, J. Air Waste Manage., 56, 709-742, 2006.

Presto, A. A., Hennigan, C. J., Nguyen, N. T., and Robinson, A. L.: Determination of volatility distributions of primary organic aerosol emissions from internal combustion engines using thermal desorption gas chromatography mass spectrometry, Aerosol Sci. Tech., 46, 1129-1139, https://doi.org/10.1080/02786826.2012.700430, 2012.

Ranjan, M., Presto, A. A., May, A. A., and Robinson, A. L.: Temperature dependence of gas-particle partitioning of primary organic aerosol emissions from a small diesel engine, Aerosol Sci. Tech., 46, 13-21, https://doi.org/10.1080/02786826.2011.602761, 2012.

Robert, M. A., VanBergen, S., Kleeman, M. J., and Jakober, C. A.: Size and composition distributions of particulate matter emissions: part 1 - light-duty gasoline vehicles, J. Air Waste Manage., 1995, 57, 1414-1428, 2007.

Robinson, A. L., Donahue, N. M., Shrivastava, M. K., Weitkamp, E. A., Sage, A. M., Grieshop, A. P., Lane, T. E., Pierce, J. R., and Pandis, S. N.: Rethinking organic aerosols: semivolatile emissions and photochemical aging, Science, 315, 1259-1262, https://doi.org/10.1126/science.1133061, 2007.

Robinson, A. L., Grieshop, A. P., Donahue, N. M., and Hunt, S. W.: Updating the conceptual model for fine particle mass emissions from combustion systems Allen L. Robinson, J. Air Waste Manage., 60, 1204-1222, https://doi.org/10.3155/10473289.60.10.1204, 2010.

Roth, C. M., Goss, K.-U., and Schwarzenbach, R. P.: Sorption of a diverse set of organic vapors to urban aerosols, Environ. Sci. Technol., 39, 6638-6643, 2005.

Saha, P. K. and Grieshop, A. P.: Exploring divergent volatility properties from yield and thermodenuder measurements of secondary organic aerosol from $\alpha$-pinene ozonolysis, Environ. Sci. Technol., 50, 5740-5749, https://doi.org/10.1021/acs.est.6b00303, 2016.

Saha, P. K., Khlystov, A., and Grieshop, A. P.: Determining aerosol volatility parameters using a "Dual Thermodenuder" system: application to laboratory-generated organic aerosols, Aerosol Sci. Tech., 49, 620-632, https://doi.org/10.1080/02786826.2015.1056769, 2015.

Saha, P. K., Khlystov, A., Yahya, K., Zhang, Y., Xu, L., Ng, N. L., and Grieshop, A. P.: Quantifying the volatility of organic aerosol in the southeastern US, Atmos. Chem. Phys., 17, 501520, https://doi.org/10.5194/acp-17-501-2017, 2017.

Saha, P. K., Khlystov, A., Snyder, M. G., and Grieshop, A. P.: Characterization of air pollutant concentrations, fleet emission factors, and dispersion near a North Carolina interstate freeway across two seasons, Atmos. Environ., 177, 143-153, https://doi.org/10.1016/j.atmosenv.2018.01.019, 2018.

Saleh, R., Shihadeh, A., and Khlystov, A.: On transport phenomena and equilibration time scales in thermodenuders, At- 
mos. Meas. Tech., 4, 571-581, https://doi.org/10.5194/amt-4571-2011, 2011.

Saleh, R., Khlystov, A., and Shihadeh, A.: Determination of evaporation coefficients of ambient and laboratory-generated semivolatile organic aerosols from phase equilibration kinetics in a thermodenuder, Aerosol Sci. Tech., 46, 22-30, https://doi.org/10.1080/02786826.2011.602762, 2012.

Saleh, R., Donahue, N. M., and Robinson, A. L.: Time scales for gas-particle partitioning equilibration of secondary organic aerosol formed from Alpha-Pinene ozonolysis, Environ. Sci. Technol., 47, 5588-5594, https://doi.org/10.1021/es400078d, 2013.

Schwarz, J. P., Gao, R. S., Fahey, D. W., Thomson, D. S., Watts, L. A., Wilson, J. C., Reeves, J. M., Darbeheshti, M., Baumgardner, D. G., Kok, G. L., Chung, S. H., Schulz, M., Hendricks, J., Lauer, A., Kärcher, B., Slowik, J. G., Rosenlof, K. H., Thompson, T. L., Langford, A. O., Loewenstein, M., and Aikin, K. C.: Single-particle measurements of midlatitude black carbon and light-scattering aerosols from the boundary layer to the lower stratosphere, J. Geophys. Res.-Atmos., 111, D16207, https://doi.org/10.1029/2006JD007076, 2006.

Shiraiwa, M., Kondo, Y., Moteki, N., Takegawa, N., Miyazaki, Y., and Blake, D. R.: Evolution of mixing state of black carbon in polluted air from Tokyo, Geophys. Res. Lett., 34, L16803, https://doi.org/10.1029/2007GL029819, 2007.

Shrivastava, M. K., Lipsky, E. M., Stanier, C. O., and Robinson, A. L.: Modeling semivolatile organic aerosol mass emissions from combustion systems, Environ. Sci. Technol., 40, 2671-2677, https://doi.org/10.1021/es0522231, 2006.

Stephens, M., Turner, N., and Sandberg, J.: Particle identification by laser-induced incandescence in a solid-state laser cavity, Appl. Optics, 42, 3726-3736, https://doi.org/10.1364/AO.42.003726, 2003.

Subramanian, R., Kok, G. L., Baumgardner, D., Clarke, A., Shinozuka, Y., Campos, T. L., Heizer, C. G., Stephens, B. B., de Foy, B., Voss, P. B., and Zaveri, R. A.: Black carbon over Mexico: the effect of atmospheric transport on mixing state, mass absorption cross-section, and BC/CO ratios, Atmos. Chem. Phys., 10, 219237, https://doi.org/10.5194/acp-10-219-2010, 2010.
Tiitta, P., Miettinen, P., Vaattovaara, P., Joutsensaari, J., Petäjä, T., Virtanen, A., Raatikainen, T., Aalto, P., Portin, H., Romakkaniemi, S., Kokkola, H., Lehtinen, K. E. J., Kulmala, M., and Laaksonen, A.: Roadside aerosol study using hygroscopic, organic and volatility TDMAs: characterization and mixing state, Atmos. Environ., 44, 976-986, https://doi.org/10.1016/j.atmosenv.2009.06.021, 2010.

Wang, J. M., Jeong, C.-H., Zimmerman, N., Healy, R. M., Hilker, N., and Evans, G. J.: Real-world emission of particles from vehicles: volatility and the effects of ambient temperature, Environ. Sci. Technol., 51, 4081-4090, https://doi.org/10.1021/acs.est.6b05328, 2017.

Willis, M. D., Healy, R. M., Riemer, N., West, M., Wang, J. M., Jeong, C.-H., Wenger, J. C., Evans, G. J., Abbatt, J. P. D., and Lee, A. K. Y.: Quantification of black carbon mixing state from traffic: implications for aerosol optical properties, Atmos. Chem. Phys., 16, 4693-4706, https://doi.org/10.5194/acp16-4693-2016, 2016.

Zhang, K. M., Wexler, A. S., Zhu, Y. F., Hinds, W. C., and Sioutas, C.: Evolution of particle number distribution near roadways, Part II: The "Road-to-Ambient" process, Atmos. Environ., 38, 6655-6665, https://doi.org/10.1016/j.atmosenv.2004.06.044, 2004.

Zhang, R., Wang, G., Guo, S., Zamora, M. L., Ying, Q., Lin, Y., Wang, W., Hu, M., and Wang, Y.: Formation of urban fine particulate matter, Chem. Rev., 115, 3803-3855, https://doi.org/10.1021/acs.chemrev.5b00067, 2015.

Zhu, Y., Hinds, W. C., Kim, S., and Sioutas, C.: Concentration and size distribution of ultrafine particles near a major highway, J. Air Waste Manage., 52, 1032-1042, https://doi.org/10.1080/10473289.2002.10470842, 2002. 